\title{
Influence of Organic and Inorganic Fertilizers on Coriander (Coriandrum sativum L.) Agronomic Traits, Essential Oil and Components under Semi-Arid Climate
}

\author{
Gülen Özyazici (D)
}

check for updates

Citation: Özyazici, G. Influence of Organic and Inorganic Fertilizers on Coriander (Coriandrum sativum L.)

Agronomic Traits, Essential Oil and Components under Semi-Arid Climate. Agronomy 2021, 11, 1427. https://doi.org/10.3390/ agronomy 11071427

Academic Editor:

Monika Mierzwa-Hersztek

Received: 31 May 2021

Accepted: 14 July 2021

Published: 17 July 2021

Publisher's Note: MDPI stays neutral with regard to jurisdictional claims in published maps and institutional affiliations.

Copyright: (C) 2021 by the author. Licensee MDPI, Basel, Switzerland. This article is an open access article distributed under the terms and conditions of the Creative Commons Attribution (CC BY) license (https:/ / creativecommons.org/licenses/by/ $4.0 /)$.
Department of Field Crops, Faculty of Agriculture, Siirt University, Siirt 56100, Turkey; gulenozyazici@siirt.edu.tr

\begin{abstract}
Environmental contamination and the excessive use of inorganic fertilizers resulting in stagnant yields of field crops which necessitate the utilization of combined fertilization approach under changing climatic conditions. Current study was aimed to clarify the influence of several fertilizer sources (chemical, organic, organomineral fertilizers) on yield and quality of coriander (Coriandrum sativum L.). The results revealed that the fertilizer sources significantly affected the yield of coriander cultivars. The absence of "Year $\times$ Variety $\times$ Fertilizer Type" interactions for any of the noted parameters signaled that the detected "Variety $\times$ Fertilizer Type" interactions were constant regardless of the year factor. The recorded values of traits according to fertilizer sources different for the plant height from 61.85 to $69.67 \mathrm{~cm}$, number of branches from 5.98 to 7.71 (piece/plant), number of umbels per the main umbel from 5.62 to 7.18 pieces, seed yield from 1.06 to $1.66 \mathrm{t} / \mathrm{ha}^{-1}$, the biological yield from 4.29 to $5.70 \mathrm{t} \mathrm{ha}^{-1}$, harvest index from 25.29 to $29.41 \%$, essential oil ratio from 0.29 to $0.33 \%$, and essential oil yield from 3.1 to $5.6 \mathrm{~L} \mathrm{ha}^{-1}$. Erbaa variety was observed to be superior over the rest of the varieties producing the maximum values of $6.5 \mathrm{~L} \mathrm{ha}^{-1}$ of essential oil, $0.36 \%$ essential oil content, $30.9 \%$ harvest index, $1.81 \mathrm{t} /$ ha seed yield, and $5.9 \mathrm{t} \mathrm{ha}^{-1}$ biological yield with the treatment of chemical fertilizers.
\end{abstract}

Keywords: Coriandrum sativum; chemical fertilizer; organic fertilizer; yield; yield components; seed oil quality

\section{Introduction}

Coriander (Coriandrum satioum L.) also called Cilantro, Arab parsley, Chinese parsley, or Kasbour [1], belongs to the family of Apiaceae (Umbelliferae) [2]. It is an annual herbaceous plant that initiated from the Mediterranean and Middle Eastern regions [3,4]. Plant grown widely all over the world [5]. It has been cultivated for many years in several regions of Iran [6] and Turkey [7]. Coriander or cilantro are the fruit and herb of Coriandrum satioum [8] known for their special fragrance. Coriander oil is a major essential oil in the global market [9]. Global coriander productivity has the largest volume as essential oil seed crops. The leafy vegetable form is becoming progressively popular in the world. Advanced breeding targets are focused on the industrial extraction of their essential oil from fruits but dual-purpose (for fruit and leaf) and sole leaf use also exist [10]. The extractable essential oil content of fruits ranges between 0.5 to $2.5 \%$ to be used as flavors to manufacture perfumes and soaps [5]. The essential oil and its main constituent, linalool is an very significant raw material in the perfume and cosmetic products, in addition, the essential oil percent of dried fruits varies from the minimum value $(0.03 \%)$ to a maximum value of $2.7 \%$ [3]. Plant contains monoterpenes, limpnene, $\alpha$-pinene, $\gamma$ terpinene, p-cymene, citronellol, borneol, camphor, coriandrin, geraniol, dihydrocoriandrin, coriandrons A-E, flavonoids and essential oils. Terpenoids are a large and diverse class of specialized metabolites essential for the growth and development of plants. The mericarps of coriander produce an essential oil-rich in monoterpenes (volatile C10 terpenoids) which have numerous industrial applications [11]. 
Fresh edible herbs represent a faster-growing market for gourmet production globally [12]. Coriander foliage is a daily spice in curry in Indian conventional foods [13]. It is a flavoring agent in food products for flavoring sweets, beverages, tobacco, bakery and curry powder [5]. Essential oils and extracts of $C$. sativum are non-toxic to humans but have various degrees of antibacterial, antifungal, antioxidative and preservative activities, which progress the shelf-life of foods [14]. Essential oils are natural and safe antioxidants and substitutes for synthetic antioxidants in food processing [15]. Plants foliage is rich in natural folates, which turns it into a natural vitamin B9 source [16]. Its seeds, leaves, and roots are edible. The herb has a light and fresh flavor. But leaves have a various taste than seeds. The source of the flavor of coriander is the significantly superior content of linoleic and furanocoumarins (coriandrin and dihydrocoriandrin) in its essential oil [17].

The popularity of conventional herbal medicines is increasing each year [18]. Coriander has antioxidant, anticancer, hypolipidemic, neuroprotective, anticonvulsant, analgesic, migraine-relieving, hypoglycemic, hypotensive, anxiolytic, antimicrobial, and antiinflammatory activities. The main compound linalool is abundant in seeds, and it's has shown a wide variety of biological activities and health benefits. It is also protective against neurodegenerative diseases, cancer, and metabolic syndrome [19]. Its ethnopharmacological use is to heal inflammatory disorders, altered blood lipid levels, respiratory and digestive problems [20]. All parts of the plant have medicinal substance, but seed oil is special in folk medicine to treat anxiety and depression [21]. The whole plant is mainly used for renal ailments diseases worldwide [22]. It has analgesic, carminative, digestive, anti-rheumatic, and antispasmodic charecters, [5]. Its nervous system activities find a place in Iranian conventional medicine [23].

C. sativum is a summer annual plant [24]. It is cultivated worldwide, and cultivar, soil nutrients, or agronomical training affect this crop significantly [25]. Its yields and chemical structures of the main bioactive constituents get influenced by genotype, variety, season, ecotype, climate, growth stage, plant part, harvesting time, and extracting process [26]. The study of Beyzi et al. [27] investigated the biochemical and bioactive properties of four different varieties from Turkey (Arslan, Gamze, Gürbüz, and Erbaa). The greatest crude oil content was extracted from the Gamze cultivar. Petroselinic acid was noted as a major fatty acid for all cultivars. The highest amount of total phenolic compounds was extracted from Arslan cultivar.

The role of $\mathrm{N}$ fertilization on coriander seed yield is important, but research on this topic is lacking [28]. Knowledge of organic and organomineral fertilizer studies in coriander is very limited. In a study, the application of vermicompost $\left(7.5 \mathrm{tha}^{-1}\right)+25 \%$ recommended NPK (25:12.5:12.5 $\left.\mathrm{kg} \mathrm{ha}^{-1}\right)$ produced the maximum biomass, seed yield, and oil yield of coriander [29]. Darzi [30] realized that the highest umbel number per plant, biomass yield, and essential oil yield were obtained with consumption of $15 \mathrm{t} \mathrm{ha}^{-1}$ cattle manure. Effect of nutrient application through organic sources on the growth, yield, and quality of coriander was studied resulting that the highest plant height, number of primary and secondary branches, number of umbels/plant, number of umbelets/umbel, number of seeds/umbel, the weight of 1000 seeds and seed yield were documented with the combination of organic sources of FYM $25 \%\left(5 \mathrm{t} \mathrm{ha}^{-1}\right)+$ Vermicompost $75 \%\left(3.75 \mathrm{tha}^{-1}\right)$ [31].

This study aimed to assess the effects of various fertilizer sources (chemical, organic, organomineral) on the yield and quality of coriander cultivars under semi-arid conditions of the Southeastern Anatolia Region of Turkey.

\section{Materials and Methods}

The experiment was conducted in 2017-2019, growing seasons at the province of the Southeastern Anatolia Region, which is located in the semi-arid climate zone of Turkey. After analyzing the climatic data of the trial location, it was measured that by average temperature for the vegetation period (November-June) was slightly higher but total precipitation was lower in the first year compared to the second year. The total amount of precipitation in the first year of the research was below the long-term average and much higher in the second year (Table 1). 
Table 1. Main climate data of the research site for the long term (1981-2019) and for the trial years [32].

\begin{tabular}{|c|c|c|c|c|c|c|c|c|c|}
\hline & \multicolumn{3}{|c|}{ Average Temperature $\left({ }^{\circ} \mathrm{C}\right)$} & \multicolumn{3}{|c|}{ Relative Humidity (\%) } & \multicolumn{3}{|c|}{ Total Precipitation (mm) } \\
\hline & Long Term & 2017-2018 & 2018-2019 & Long Term & 2017-2018 & 2018-2019 & Long Term & 2017-2018 & 2018-2019 \\
\hline November & 10.6 & 11.2 & 11.0 & 72.3 & 64.4 & 76.2 & 74.3 & 85.2 & 93.6 \\
\hline December & 5.1 & 8.0 & 6.6 & 67.1 & 65.2 & 82.4 & 90.6 & 46.8 & 188.6 \\
\hline January & 3.2 & 5.7 & 4.0 & 72.5 & 70.5 & 72.5 & 81.3 & 65.0 & 94.4 \\
\hline February & 4.7 & 8.2 & 5.8 & 67.3 & 67.7 & 66.9 & 96.4 & 75.6 & 110.6 \\
\hline March & 9.1 & 13.7 & 8.3 & 61.3 & 55.9 & 67.4 & 108.8 & 47.2 & 185.2 \\
\hline April & 14.2 & 16.8 & 11.9 & 58.3 & 47.6 & 66.8 & 101.7 & 60.8 & 167.0 \\
\hline May & 19.7 & 19.8 & 21.9 & 50.2 & 59.1 & 42.1 & 63.8 & 146.8 & 1.3 \\
\hline June & 26.5 & 27.4 & 29.1 & 34.2 & 31.7 & 26.9 & 9.4 & 3.0 & 0.0 \\
\hline Total/Average & 11.6 & 13.9 & 12.3 & 60.4 & 57.8 & 62.7 & 626.3 & 530.4 & 840.7 \\
\hline
\end{tabular}

Some physical and chemical properties of the soil samples taken from fields at a depth of 0-20 cm before trials is given in Table 1 . Study soils were in clay texture, slightly alkaline and non-saline with low organic matter content, medium lime content, very low available phosphorus content, and sufficient available potassium content (Table 2).

Table 2. Major physical and chemical properties of the trail field soils $(0-20 \mathrm{~cm})$.

\begin{tabular}{lcc}
\hline \multirow{2}{*}{ Soil Properties } & & Values \\
\cline { 2 - 3 } & $\mathbf{2 0 1 7 - 2 0 1 8}$ & $\mathbf{2 0 1 8 - 2 0 1 9}$ \\
\hline Clay $(\%)$ & 55.84 & 58.00 \\
Sand (\%) & 7.90 & 14.00 \\
Silt (\%) & 36.26 & 28.00 \\
$\mathrm{pH}$ & 7.98 & 7.95 \\
Organic matter (\%) & 1.31 & 1.58 \\
Lime $\left(\mathrm{CaCO}_{3}\right)(\%)$ & 13.0 & 10.5 \\
Electrical conductivity $\left(\mathrm{dS} \mathrm{m}^{-1}\right)$ & 0.363 & 0.575 \\
Available Phosphorus $(\mathrm{P})\left(\mathrm{kg} \mathrm{P}_{2} \mathrm{O}_{5} \mathrm{ha}^{-1}\right)$ & 29 & 35 \\
Available Potassium $(\mathrm{K})\left(\mathrm{kg} \mathrm{K}_{2} \mathrm{O} \mathrm{ha}^{-1}\right)$ & 1350 & 1180 \\
\hline
\end{tabular}

Analyzes were conducted in Siirt University Science and Technology Application and Research Center Laboratory.

In the experimental field, after wheat harvesting, the field was plowed and prepared for planting. Coriander varieties "Arslan" and "Erbaa" were used in the research as planting material. The experiments were established in a split-plot design with four replications. Four rows were planted in each plot with a $30 \mathrm{~cm}$ inter-row distance. The plot length was $4 \mathrm{~m}$, and the parcel area was $1.2 \mathrm{~m} \times 4=4.8 \mathrm{~m}^{2}$. Distance between the parcels and blocks was $1 \mathrm{~m}$. Two varieties were placed in the main plots, and four types of fertilizers management viz., control (zero fertilizer), chemical fertilizer, organomineral fertilizer, and vermicompost were placed in the sub-plots.

Pre-sowing soil analysis was performed for the determination of the chemical and organomineral fertilizers amount to be applied. We applied $\mathrm{P}_{2} \mathrm{O}_{5}$ at $60 \mathrm{~kg} \mathrm{ha}^{-1}$ as a form of triple superphosphate $\left(42 \% \mathrm{P}_{2} \mathrm{O}_{5}\right)$ and mixed it into the soil in planting time for the chemical fertilizer. Half of the nitrogen $(\mathrm{N})$ fertilizer was given in planting, while the second half was applied during the stem elongation period, with an account of $80 \mathrm{~kg}$ $\mathrm{N} \mathrm{ha}{ }^{-1}$ in the form of urea $(46 \% \mathrm{~N})$. Potassium fertilizer was not applied because the soil of the study area contains sufficient potassium. Organomineral fertilizer application parcels received $20-15-0 \%$ solid organomineral fertilizer during planting and then solid organomineral fertilizer containing $30 \% \mathrm{~N}$ at the stem elongation period. Vermicompost (solid worm manure) was used as an organic fertilizer and applied to the soil 15 days before planting at a $3 \mathrm{t} \mathrm{ha}^{-1}$ rate. Specifications of the vermicompost used in the study were as follows: $\mathrm{EC}$ value $=3.2 \mathrm{dS} \mathrm{m}^{-1}, \mathrm{pH}$ value $=6.8$, organic matter content $=57 \%$, total nitrogen $(\mathrm{N})$ content $=3.1 \%, \mathrm{C} / \mathrm{N}$ ratio $=9.2$, total $\mathrm{P}\left(\mathrm{P}_{2} \mathrm{O}_{5}\right)$ content $=1.2 \%$, water-soluble $\mathrm{K}_{2} \mathrm{O}=0.89 \%$. 
The coriander seed was sown manually to the lines at $20 \mathrm{~kg} \mathrm{ha}^{-1}$. Sowing was done on 09th November, 2017 and 07th November, 2018. Hand weeding was done several times to control weeds in both years. No irrigation was applied as spring rains were sufficient. The harvesting was performed at the yellowish-brown seed stage. The middle two rows in each parcel were harvested and used for yield data collection.

Plant height $(\mathrm{cm})$, number of branches (pieces/plant), number of umbelets per the main umbel (pieces), thousand seed weight $(\mathrm{g})$, seed yield $\left(\mathrm{kg} \mathrm{ha}^{-1}\right)$, biological yield $\left(\mathrm{kg} \mathrm{ha}^{-1}\right)$, harvest index (\%), essential oil ratio (\%), and essential oil yield ( $\mathrm{L} \mathrm{ha}^{-1}$ ) properties were investigated in the study. The essential oil ratio was determined by the watersteam distillation method in the Neo-Clevenger appliance. The essential oil ratio was determined by adding $500 \mathrm{~mL}$ of distilled water to the grounded $50 \mathrm{~g}$ seed sample and boiling at $130{ }^{\circ} \mathrm{C}$ for $4 \mathrm{~h}$. Components of the essential oil were determined by using gas chromatography. Operating conditions of the device were: System: Thermo Fisher Scientific, Austin, TX; Colon: Thermo TG-WAXMS GC colon $(60 \mathrm{~m} \times 0.25 \mathrm{~mm} \mathrm{ID} \times 0.25 \mathrm{um})$; Temperature Program: $10 \mathrm{~min}$ at $60{ }^{\circ} \mathrm{C} / / 4^{\circ} \mathrm{C} / \mathrm{min}$ increments until $230{ }^{\circ} \mathrm{C} / / 10 \mathrm{~min}$ at $230{ }^{\circ} \mathrm{C} / / 1{ }^{\circ} \mathrm{C} / \mathrm{min}$ increments until $250{ }^{\circ} \mathrm{C}$; Injector: $250{ }^{\circ} \mathrm{C}$; Carrier Gas: Helium (1.2 mL/min); Mass spectral scanning range: 55-550 (amu); Peak identification was performed by comparison of stored known components in NIST Demo, Wiley7, Wiley9, redlip, mainlip, WinRI (NIST, Gaithersburg, MD, USA).

The data obtained from the study were subjected to the homogeneity test, and the analysis of variance, which was combined with the data found homogeneous according to the random blocks trial design was performed using the JMP 5.0 statistical program. Differences between groups was tested via F test and means were determined by Tukey's multiple comparison test at 0.05 significance level [33].

\section{Results and Discussion}

Fertilizer sources and the variety significantly influenced the plant height of the coriander. However, their interactions were not significant (Table 3). Considering the fertilizer sources, the lowest $(61.85 \mathrm{~cm})$ and the highest $(69.67 \mathrm{~cm})$ plant height was obtained from control and chemical fertilizers, respectively. Considering the variety, the Erbaa produced a taller plant $(76.50 \mathrm{~cm})$ than the Arslan variety $(35.03 \mathrm{~cm})$. It is thought that the differences between the cultivars in terms of plant height are due to the diverse genotypic structures of the cultivars. These variations can be attributed to differnt factor like climatic conditions, species and growing conditions [34].

Number of branches was different for cultivars. The two-year average number of branches of the Erbaa variety (7.2 pieces) was higher than the value of the Arslan variety (6.6 pieces) (Table 4). Application of various types of fertilizer influenced the number of branches per plant. Plants under control conditions produced the lowest number of branches (5.98 pieces), while the highest number of branches (7.71 pieces) were achieved from the plants treated with chemical fertilizers (Table 4). Various types of fertilizer distinguished the number of umbelets per plant. The lowest number of umbelets per umbel (5.62 pieces) was achieved by control application. Other applications produced a group of higher similar values (Table 5). As it is known, the number of branches and umbelet are a feature depends on the genotype, but they are greatly affected by the ecological conditions and cultivation techniques in which the plant grows [35].

The year significantly influenced the biological yield of coriander. The average biological yield (5.42 $\left.\mathrm{t} \mathrm{ha}^{-1}\right)$ was higher in the second year than the first year $\left(4.55 \mathrm{t} \mathrm{ha}^{-1}\right)$ (Table 6). 
Table 3. Effect of fertilizer types on plant height of coriander varieties $(\mathrm{cm})^{1}$.

\begin{tabular}{|c|c|c|c|c|c|}
\hline \multirow{2}{*}{ Varieties } & \multicolumn{4}{|c|}{ Fertilizer Types } & \multirow{2}{*}{ Averages } \\
\hline & Control & Chemical Fertilizer & Organomineral Fertilizer & Organic Fertilizer & \\
\hline \multicolumn{6}{|c|}{ Year 2017-2018 } \\
\hline Arslan & 53.13 & 58.53 & 53.80 & 57.20 & 55.67 \\
\hline Erbaa & 69.20 & 80.33 & 76.27 & 74.27 & 75.02 \\
\hline Averages & 61.17 & 69.43 & 65.03 & 65.73 & 65.34 \\
\hline \multicolumn{6}{|c|}{ Year 2018-2019 } \\
\hline Arslan & 51.42 & 56.67 & 55.39 & 54.13 & 54.40 \\
\hline Erbaa & 73.63 & 83.13 & 77.87 & 77.30 & 77.98 \\
\hline Averages & 62.52 & 69.90 & 66.63 & 65.72 & 66.19 \\
\hline \multicolumn{6}{|c|}{ Averages } \\
\hline Arslan & 52.28 & 57.60 & 54.59 & 55.67 & $55.03 \mathrm{~b}$ \\
\hline Erbaa & 71.42 & 81.73 & 77.07 & 75.78 & $76.50 \mathrm{a}$ \\
\hline Averages & $61.85 \mathrm{C}$ & $69.67 \mathrm{~A}$ & $65.83 \mathrm{~B}$ & $65.73 \mathrm{~B}$ & \\
\hline
\end{tabular}

Level of Significance

Year (Y): 0.4023, Variety (V): $0.0001^{* *}$, Fertilizer Types (FT): 0.0001 ** Y × V: 0.0806, Y × FT: 0.8387, V × FT: 0.0819, $\mathrm{Y} \times \mathrm{V} \times \mathrm{FT}: 0.3968$

${ }^{1}$ The difference between the averages represented with the same letter in the same column/same group is not statistically significant.

**: Significant at $p<0.01$ level.

Table 4. The effect of fertilizer types on the number of branches in coriander varieties (pieces) ${ }^{1}$.

\begin{tabular}{|c|c|c|c|c|c|}
\hline \multirow{2}{*}{ Varieties } & \multicolumn{4}{|c|}{ Fertilizer Types } & \multirow{2}{*}{ Averages } \\
\hline & Control & Chemical Fertilizer & Organomineral Fertilizer & Organic Fertilizer & \\
\hline \multicolumn{6}{|c|}{ Year 2017-2018 } \\
\hline Arslan & 6.20 & 7.07 & 6.72 & 5.97 & 6.49 \\
\hline Erbaa & 6.56 & 8.04 & 7.54 & 7.72 & 7.47 \\
\hline Averages & 6.38 & 7.56 & 7.13 & 6.84 & 6.98 \\
\hline \multicolumn{6}{|c|}{ Year 2018-2019 } \\
\hline Arslan & 5.52 & 7.64 & 6.98 & 6.59 & 6.68 \\
\hline Erbaa & 5.65 & 8.07 & 7.41 & 6.73 & 6.97 \\
\hline Averages & 5.58 & 7.86 & 7.20 & 6.66 & 6.82 \\
\hline \multicolumn{6}{|c|}{ Averages } \\
\hline Arslan & 5.86 & 7.36 & 6.85 & 6.27 & $6.58 \mathrm{~b}$ \\
\hline Erbaa & 6.10 & 8.06 & 7.47 & 7.23 & $7.22 \mathrm{a}$ \\
\hline Averages & $5.98 \mathrm{D}$ & $7.71 \mathrm{~A}$ & $7.16 \mathrm{~B}$ & $6.75 \mathrm{C}$ & \\
\hline
\end{tabular}

Level of Significance

Year (Y): 0.3460, Variety (V): $0.0117^{*}$, Fertilizer Type (FT): 0.0001 **, Y $\times$ V: 0.0718, Y × FT: $0.0784, \mathrm{~V} \times$ FT: $0.3200, \mathrm{Y} \times \mathrm{V} \times$ FT: 0.2642

${ }^{1}$ The difference between the averages represented with the same letter in the same column/same group is not statistically significant.

*: Significant at $p<0.05$ level, ${ }^{* *}$ : Significant at $p<0.01$ level. 
Table 5. The effect of fertilizer types on the number of umbelets per umbel in coriander varieties (pieces) ${ }^{1}$.

\begin{tabular}{|c|c|c|c|c|c|}
\hline \multirow{2}{*}{ Varieties } & \multicolumn{4}{|c|}{ Fertilizer Types } & \multirow{2}{*}{ Averages } \\
\hline & Control & Chemical Fertilizer & Organomineral Fertilizer & Organic Fertilizer & \\
\hline \multicolumn{6}{|c|}{ Year 2017-2018 } \\
\hline Arslan & 5.63 & 5.89 & 6.44 & 6.65 & 6.15 \\
\hline Erbaa & 5.72 & 8.28 & 7.44 & 6.71 & 7.04 \\
\hline Averages & $5.68 \mathrm{bc}$ & $7.08 \mathrm{a}$ & $6.94 \mathrm{ab}$ & $6.68 \mathrm{abc}$ & 6.59 \\
\hline \multicolumn{6}{|c|}{ Year 2018-2019 } \\
\hline Arslan & 5.40 & 5.90 & 6.27 & 6.16 & 5.93 \\
\hline Erbaa & 5.76 & 8.67 & 8.30 & 7.39 & 7.53 \\
\hline Averages & $5.58 \mathrm{c}$ & $7.28 \mathrm{a}$ & $7.28 \mathrm{a}$ & $6.78 \mathrm{abc}$ & 6.73 \\
\hline \multicolumn{6}{|c|}{ Averages } \\
\hline Arslan & $5.52 \mathrm{~d}$ & $5.89 \mathrm{~cd}$ & $6.35 \mathrm{~cd}$ & $6.41 \mathrm{~cd}$ & 6.04 \\
\hline Erbaa & $5.73 \mathrm{~d}$ & $8.47 \mathrm{a}$ & $7.87 \mathrm{ab}$ & $7.05 \mathrm{bc}$ & 7.28 \\
\hline Averages & $5.62 \mathrm{~B}$ & $7.18 \mathrm{~A}$ & $7.11 \mathrm{~A}$ & $6.73 \mathrm{~A}$ & \\
\hline
\end{tabular}

Level of Significance

Year (Y): 0.8043, Variety (V): 0.0729, Fertilizer Type (FT): 0.0001 ** Y × V: 0.6593, Y × FT: 0.2049, V × FT: 0.0885, Y × V × FT: 0.3654

${ }^{1}$ The difference between the averages represented with the same letter in the same column/same group is not statistically significant.

$* *$ : Significant at $p<0.01$ level.

Table 6. Effect of fertilizer types on biological yield of coriander varieties $\left(\mathrm{t} \mathrm{ha}^{-1}\right)^{1}$.

\begin{tabular}{|c|c|c|c|c|c|}
\hline \multirow{2}{*}{ Varieties } & \multicolumn{4}{|c|}{ Fertilizer Types } & \multirow{2}{*}{ Averages } \\
\hline & Control & Chemical Fertilizer & Organomineral Fertilizer & Organic Fertilizer & \\
\hline \multicolumn{6}{|c|}{ Year 2017-2018 } \\
\hline Arslan & 3.41 & 4.75 & 4.20 & 3.94 & 4.07 \\
\hline Erbaa & 4.52 & 5.56 & 5.03 & 5.01 & 5.03 \\
\hline Averages & 3.96 & 5.15 & 4.62 & 4.47 & $4.55 \mathrm{~b}$ \\
\hline \multicolumn{6}{|c|}{ Year 2018-2019 } \\
\hline Arslan & 4.09 & 6.32 & 5.44 & 5.23 & 5.27 \\
\hline Erbaa & 5.13 & 6.18 & 5.66 & 5.36 & 5.58 \\
\hline Averages & 4.60 & 6.25 & 5.55 & 5.30 & $5.42 \mathrm{a}$ \\
\hline \multicolumn{6}{|c|}{ Averages } \\
\hline Arslan & $3.74 \mathrm{e}$ & $5.53 \mathrm{ab}$ & $4.82 \mathrm{~cd}$ & $4.58 \mathrm{~d}$ & 4.67 \\
\hline Erbaa & $4.82 \mathrm{~cd}$ & $5.87 \mathrm{a}$ & $5.35 \mathrm{abc}$ & $5.19 \mathrm{bc}$ & 5.30 \\
\hline Averages & $4.29 \mathrm{C}$ & $5.70 \mathrm{~A}$ & $5.08 \mathrm{~B}$ & $4.88 \mathrm{~B}$ & \\
\hline \multicolumn{6}{|c|}{ Level of Significance } \\
\hline Year ( & 0320 *, Va & ): 0.0793, Fertilizer Ty & $\begin{array}{l}\text { ): } 0.0001^{* *}, Y \times V: 0.3018, Y \\
\text { FT: } 0.1951\end{array}$ & FT: $0.2656, \mathrm{~V} \times \mathrm{FT}:$ & $209 *$ \\
\hline
\end{tabular}

${ }^{1}$ The difference between the averages represented with the same letter in the same column/same group is not statistically significant.

*: Significant at $p<0.05$ level, **: Significant at $p<0.01$ level.

Chemical fertilizers produced the highest biological yield $\left(5.70 \mathrm{t} \mathrm{ha}^{-1}\right)$ and the lowest $\left(4.29 \mathrm{tha}^{-1}\right)$ biological yield was achieved in by control condition where no treatment was applied (Table 6).

The interaction of variety $\times$ types of fertilizer significantly affected the biological yield. The highest biological yield $\left(5.87 \mathrm{t} \mathrm{ha}^{-1}\right)$ was produced with chemical fertilizer in Erbaa variety, and the lowest $\left(3.74 \mathrm{t} \mathrm{ha}^{-1}\right)$ was in the control condition in the Arslan variety. However, values achieved with the organomineral application to the Erbaa variety and 
chemical fertilizer to the Arslan variety was close to the highest value (Table 6).Application of vermicompost $\left(7.5 \mathrm{tha}^{-1}\right)+25 \%$ advised NPK $\left(25: 12.5: 12.5 \mathrm{~kg} \mathrm{ha}^{-1}\right)$ acjieved the greatest biomass, seed yield, and oil yield of coriander [29].

Climate had effectively influenced the seed yield. The average seed yield of the second year $\left(1.47 \mathrm{t} \mathrm{ha}^{-1}\right)$ was higher than the value of the first year $\left(1.33 \mathrm{tha} \mathrm{h}^{-1}\right)$ (Table 7$)$. The climatic variances clarify the responses of all coriander cultivars were produced high fruit yield to the conditions [34].

Table 7. The effect of fertilizer types on seed yield of coriander varieties $\left(\mathrm{t} \mathrm{ha}^{-1}\right)^{1}$.

\begin{tabular}{|c|c|c|c|c|c|}
\hline \multirow{2}{*}{ Varieties } & \multicolumn{4}{|c|}{ Fertilizer Types } & \multirow{2}{*}{ Averages } \\
\hline & Control & Chemical Fertilizer & Organomineral Fertilizer & Organic Fertilizer & \\
\hline \multicolumn{6}{|c|}{ Year 2017-2018 } \\
\hline Arslan & 0.99 & 1.44 & 1.32 & 1.23 & 1.25 \\
\hline Erbaa & 1.04 & 1.72 & 1.54 & 1.38 & 1.42 \\
\hline Averages & 1.02 & 1.58 & 1.43 & 1.31 & $1.33 \mathrm{~b}$ \\
\hline \multicolumn{6}{|c|}{ Year 2018-2019 } \\
\hline Arslan & 1.05 & 1.60 & 1.47 & 1.40 & 1.38 \\
\hline Erbaa & 1.17 & 1.89 & 1.68 & 1.51 & 1.56 \\
\hline Averages & 1.11 & 1.74 & 1.57 & 1.46 & $1.47 \mathrm{a}$ \\
\hline \multicolumn{6}{|c|}{ Averages } \\
\hline Arslan & $1.02 \mathrm{f}$ & $1.52 \mathrm{c}$ & $1.39 \mathrm{de}$ & $1.32 \mathrm{e}$ & $1.31 \mathrm{~b}$ \\
\hline Erbaa & $1.11 \mathrm{f}$ & $1.81 \mathrm{a}$ & $1.61 \mathrm{~b}$ & $1.45 \mathrm{~cd}$ & $1.49 \mathrm{a}$ \\
\hline Averages & $1.06 \mathrm{D}$ & $1.66 \mathrm{~A}$ & $1.50 \mathrm{~B}$ & $1.38 \mathrm{C}$ & \\
\hline
\end{tabular}

Level of Significance

Year (Y): $0.0233^{*}$, Variety (V): 0.0093, Fertilizer Type $(\mathrm{FT}): 0.0001^{* *}, \mathrm{Y} \times \mathrm{V}: 0.9347, \mathrm{Y} \times \mathrm{FT}: 0.3462, \mathrm{~V} \times \mathrm{FT}: 0.0001$ **, $\mathrm{Y} \times \mathrm{V} \times \mathrm{FT}: 0.4961$

${ }^{1}$ The difference between the averages represented with the same letter in the same column/same group is not statistically significant.

*: Significant at $p<0.05$ level, ${ }^{* *}$ : Significant at $p<0.01$ level.

The two-year average seed yield of Erbaa variety $\left(1.49 \mathrm{t} \mathrm{ha}^{-1}\right)$ was higher than the value of the Arslan variety $\left(1.31 \mathrm{tha}^{-1}\right)$ (Table 7$)$. The chemical fertilization significantly improved the seed yield. The lowest $(1.06 \mathrm{t} / \mathrm{ha})$ and the highest $\left(1.66 \mathrm{t} \mathrm{ha}^{-1}\right)$ seed yields were observed with control application and chemical fertilizer application, respectively (Table 7). Variety $\times$ fertilizer type interaction was significant on the seed yield. The lowest seed yield values (1.02 and $1.11 \mathrm{t} \mathrm{ha}^{-1}$ ) were obtained with the control applications in Arslan and Erbaa varieties, respectively.Instead, the highest seed yield value $\left(1.81 \mathrm{t} \mathrm{ha}^{-1}\right)$ was obtained with chemical fertilizer to Erbaa variety (Table 7). An increase in seed yield occurred with increasing rainfall in the second year. Types of fertilizer had a significant effect on the harvest index. However, the lowest harvest index value (25.29\%) was found with the control application. Other applications produced a group of higher similar values (Table 8). It was found that the maximum biomass yield, and essential oil yield were produced by using of $15 \mathrm{t} \mathrm{ha}^{-1}$ cattle manure [30].

"Variety $\times$ Fertilizer Type" interaction was significant on harvest index. The lowest $(23.04 \%)$ and the highest $(30.86 \%)$ harvest index values were produced by control application of Erbaa variety and chemical fertilizer application of Erbaa variety, respectively.Though, all applications treatments except the control application of both varieties produced values near to the highest value (Table 8 ). The essential oil ratio was different for the cultivars; the two-year average oil ratio of the Erbaa variety $(0.34 \%)$ was higher than the value of the Arslan variety ( $0.29 \%$ ) (Table 9 ). Nutrient supplementation through organic sources on the quality of coriander was studied resulting that the maximum oil ratio as recorded with the combination of organic sources of FYM 25\% $\left(5 \mathrm{tha}^{-1}\right)+$ Vermicompost $75 \%\left(3.75 \mathrm{tha}^{-1}\right)$ [31]. 
Table 8. The effect of fertilizer types on the harvest index of coriander varieties $(\%)^{1}$.

\begin{tabular}{|c|c|c|c|c|c|}
\hline \multirow{2}{*}{ Varieties } & \multicolumn{4}{|c|}{ Fertilizer Types } & \multirow{2}{*}{ Averages } \\
\hline & Control & Chemical Fertilizer & Organomineral Fertilizer & Organic Fertilizer & \\
\hline \multicolumn{6}{|c|}{ Year 2017-2018 } \\
\hline Arslan & 29.35 & 30.57 & 31.93 & 31.78 & 30.91 \\
\hline Erbaa & 23.19 & 30.98 & 30.65 & 27.87 & 28.17 \\
\hline Averages & 26.27 & 30.77 & 31.29 & 29.83 & 29.54 \\
\hline \multicolumn{6}{|c|}{ Year 2018-2019 } \\
\hline Arslan & 25.75 & 25.37 & 27.43 & 27.11 & 26.42 \\
\hline Erbaa & 22.89 & 30.73 & 29.78 & 28.24 & 27.91 \\
\hline Averages & 24.32 & 28.05 & 28.61 & 27.68 & 27.16 \\
\hline \multicolumn{6}{|c|}{ Averages } \\
\hline Arslan & $27.55 \mathrm{c}$ & $27.97 \mathrm{bc}$ & $29.69 \mathrm{abc}$ & $29.45 a b c$ & 28.66 \\
\hline Erbaa & $23.04 \mathrm{~d}$ & $30.86 \mathrm{a}$ & $30.22 \mathrm{ab}$ & $28.06 \mathrm{bc}$ & 28.04 \\
\hline Averages & $25.29 \mathrm{~B}$ & $29.41 \mathrm{~A}$ & $29.95 \mathrm{~A}$ & $28.75 \mathrm{~A}$ & \\
\hline
\end{tabular}

Level of Significance

Year (Y): 0.1867, Variety (V): 0.6978, Fertilizer Type (FT): $0.0001^{* *}, \mathrm{Y} \times$ V: 0.2297, Y $\times$ FT: 0.9545, V × FT: 0.0014 **, $\mathrm{Y} \times \mathrm{V} \times \mathrm{FT}: 0.9337$

${ }^{1}$ The difference between the averages represented with the same letter in the same column/same group is not statistically significant.

**: Significant at $p<0.01$ level.

Table 9. The effect of fertilizer types on the essential oil ratio of coriander varieties $(\%)^{1}$.

\begin{tabular}{|c|c|c|c|c|c|}
\hline \multirow{2}{*}{ Varieties } & \multicolumn{4}{|c|}{ Fertilizer Types } & \multirow{2}{*}{ Averages } \\
\hline & Control & Chemical Fertilizer & Organomineral Fertilizer & Organic Fertilizer & \\
\hline \multicolumn{6}{|c|}{ Year 2017-2018 } \\
\hline Arslan & 0.27 & 0.31 & 0.30 & 0.29 & 0.29 \\
\hline Erbaa & 0.31 & 0.35 & 0.35 & 0.34 & 0.34 \\
\hline Averages & 0.29 & 0.33 & 0.32 & 0.32 & 0.31 \\
\hline \multicolumn{6}{|c|}{ Year 2018-2019 } \\
\hline Arslan & 0.28 & 0.31 & 0.30 & 0.30 & 0.30 \\
\hline Erbaa & 0.30 & 0.37 & 0.35 & 0.34 & 0.34 \\
\hline Averages & 0.29 & 0.34 & 0.33 & 0.32 & 0.32 \\
\hline \multicolumn{6}{|c|}{ Averages } \\
\hline Arslan & $0.27 \mathrm{~d}$ & $0.31 \mathrm{c}$ & $0.30 \mathrm{c}$ & $0.30 c$ & $0.29 \mathrm{~b}$ \\
\hline Erbaa & $0.31 \mathrm{c}$ & $0.36 \mathrm{a}$ & $0.35 \mathrm{ab}$ & $0.34 \mathrm{~b}$ & $0.34 \mathrm{a}$ \\
\hline Averages & $0.29 \mathrm{C}$ & $0.33 \mathrm{~A}$ & $0.32 \mathrm{~B}$ & $0.32 \mathrm{~B}$ & \\
\hline
\end{tabular}

Level of Significance

Year (Y): 0.1976, Variety (V): $0.0001^{* *}$, Fertilizer Type (FT): $0.0001^{* *}, \mathrm{Y} \times$ V: 0.8722, Y $\times$ FT: 0.3438, V $\times$ FT: $0.0107^{*}$, $\mathrm{Y} \times \mathrm{V} \times$ FT: 0.2295

${ }^{1}$ The difference between the averages represented with the same letter in the same column/same group is not statistically significant.

*: Significant at $p<0.05$ level, ${ }^{* *}$ : Significant at $p<0.01$ level.

Fertilizer type was distinguished the essential oil ratio; the lowest $(0.29 \%)$ and the highest value $(0.33 \%)$ of oil ratio was obtained with the control and chemical fertilizer application, respectively (Table 9). "Variety $\times$ Fertilizer Type" interaction was significant on oil ratio. The lowest $(0.27 \%)$ and highest $(0.36 \%)$ oil content values were produced by control application of Arslan variety and by chemical fertilizer application of Erbaa variety, respectively. In addition, the organomineral fertilizer application of the Erbaa variety also produced a value near to the highest value (Table 9). Beyzi et al. [27] reported that, the 
oil contents of different coriander varieties can be affected by the fruit size. Small-fruit types contain higher oil compared with large-fruited types and the oil composition of seeds can be affected by several factors, such as genetic structure, climatic conditions, soil macro and micronutrient, and agricultural applications [34]. Climate was effective on seed yield; average oil yields in the second year $\left(4.8 \mathrm{~L} \mathrm{ha}^{-1}\right)$ were higher than the in first year $\left(4.3 \mathrm{~L} \mathrm{ha}^{-1}\right)$ (Table 10). Application organic sources on the oil yield and quality of crop was studied resulting that the highest plant oil yield was documented with the combination of organic sources of FYM 25\% $\left(5 \mathrm{tha}^{-1}\right)+$ Vermicompost $75 \%\left(3.75 \mathrm{tha}^{-1}\right)$ [31].

Table 10. Effect of fertilizer types on essential oil yield of coriander varieties $\left(\mathrm{L} \mathrm{ha}^{-1}\right) .{ }^{1}$.

\begin{tabular}{|c|c|c|c|c|c|}
\hline \multirow{2}{*}{ Varieties } & \multicolumn{4}{|c|}{ Fertilizer Types } & \multirow{2}{*}{ Averages } \\
\hline & Control & Chemical Fertilizer & Organomineral Fertilizer & Organic Fertilizer & \\
\hline \multicolumn{6}{|c|}{ Year 2017-2018 } \\
\hline Arslan & 2.7 & 4.4 & 3.9 & 3.6 & 3.7 \\
\hline Erbaa & 3.2 & 6.0 & 5.4 & 4.8 & 4.8 \\
\hline Averages & 3.0 & 5.2 & 4.6 & 4.2 & $4.3 \mathrm{~b}$ \\
\hline \multicolumn{6}{|c|}{ Year 2018-2019 } \\
\hline Arslan & 2.9 & 5.0 & 4.4 & 4.2 & 4.1 \\
\hline Erbaa & 3.5 & 6.9 & 5.9 & 5.2 & 5.4 \\
\hline Averages & 3.2 & 6.0 & 5.2 & 4.7 & $4.8 \mathrm{a}$ \\
\hline \multicolumn{6}{|c|}{ Averages } \\
\hline Arslan & $2.8 \mathrm{f}$ & $4.7 \mathrm{c}$ & $4.1 \mathrm{~d}$ & $3.9 \mathrm{~d}$ & $3.9 \mathrm{~b}$ \\
\hline Erbaa & $3.4 \mathrm{e}$ & $6.5 \mathrm{a}$ & $5.7 \mathrm{~b}$ & $5.0 \mathrm{c}$ & $5.1 \mathrm{a}$ \\
\hline Averages & $3.1 \mathrm{D}$ & $5.6 \mathrm{~A}$ & $5.0 \mathrm{~B}$ & $4.5 \mathrm{C}$ & \\
\hline \multicolumn{6}{|c|}{ Level of Significance } \\
\hline Year $(Y): 0$ & Variety $(\mathrm{V}$ & **, Fertilizer Type $(\mathrm{FT})$ & $\mathrm{Y} \times \mathrm{V}: 0.7442, \mathrm{Y} \times \mathrm{FT}: 0.05$ & $\times$ FT: $0.0001^{* *}, \mathrm{Y} \times$ & T: 0.4098 \\
\hline
\end{tabular}

1 The difference between the averages represented with the same letter in the same column/same group is not statistically significant.

*: Significant at $p<0.05$ level, ${ }^{* *}$ : Significant at $p<0.01$ level.

Essential oil yield different across cultivars; the two-year average oil yield of the Erbaa variety (5.1 $\mathrm{L} \mathrm{ha}^{-1}$ ) was higher than the Arslan variety (3.9 $\mathrm{L} \mathrm{ha}^{-1}$ ) (Table 10). Fertilizer type was differentiated from the essential oil yield; lowest $\left(3.1 \mathrm{~L} \mathrm{ha}^{-1}\right)$ and highest $\left(5.6 \mathrm{~L} \mathrm{ha}^{-1}\right)$ oil yield values were achieved by control and chemical fertilizer application, respectively (Table 10). "Variety $\times$ Fertilizer Type" interaction was significant on essential oil yield. The lowest $\left(2.8 \mathrm{~L} \mathrm{ha}^{-1}\right)$ and the highest $\left(6.5 \mathrm{~L} \mathrm{ha}^{-1}\right)$ essential oil yield values were produced by control application of Arslan variety and chemical fertilizer application of Erbaa variety, respectively (Table 10). In essential oils, 12 components were determined in the Arslan variety in both years, whereas ten components in the first year and 8 components in the second year were determined in the Erbaa variety (Tables 11 and 12). It was reported that oil composition was sensitive to the year variation in climate conditions as well as in soil conditions [35].

Linalool was the dominant essential oil component for both coriander varieties. Linalool content of the Arslan variety was between $69.62-73.17 \%$ in the first year and $73.40-75.91 \%$ in the second year in relation to fertilizer type. In the Erbaa variety, the ratio of the linalool component was between $80.46-82.80 \%$ in the first year and $85.03-90.12 \%$ in the second year. Beyzi et al. [27] stated that linalool, the main essential oil component, was found in the highest cultivar Erbaa. As a result of organomineral and organic fertilizer applications, a slight increase in linalool content was found in both coriander varieties in the study compared to the control. The linalool ratios obtained from coriander plants may vary depending on the cultivars and environmental conditions. Moreover, the fertilizers mediated transcriptional regulatory molecular mechanism behind the overall improvement in agronomic and nutritional traits is also important from the sustainability perspective [36]. 
Table 11. Essential oil components of Arslan coriander variety (\%).

\begin{tabular}{|c|c|c|c|c|c|}
\hline \multirow{2}{*}{ R.T * } & \multirow{2}{*}{ Component Names } & \multicolumn{4}{|c|}{ Fertilizer Types } \\
\hline & & Control & Chemical Fertilizer & Organomineral Fertilizer & Organic Fertilizer \\
\hline & & & & & \\
\hline 16.21 & Ç-terpinene & 6.81 & 6.32 & 5.17 & 5.02 \\
\hline 17.19 & Benzene, 1-methyl-2-(1-methylethyl) & 2.36 & 1.81 & 1.47 & 1.80 \\
\hline 25.13 & Decanal & 1.92 & 2.01 & 0.9 & 2.15 \\
\hline 25.99 & Camphor & 3.11 & 1.55 & 2.05 & 1.55 \\
\hline 26.78 & 1-octanol & 2.17 & 3.01 & 2.96 & 0.79 \\
\hline 29.76 & 2-Decenal & 0.64 & 0.98 & 0.76 & 0.51 \\
\hline 32.86 & 1-Decanal & 8.98 & 6.08 & 7.88 & 8.72 \\
\hline 34.42 & Cyclodecanol & 1.00 & 1.92 & 1.24 & 1.97 \\
\hline 34.42 & Trans-2-dodecenil-ol & 1.00 & 1.94 & 1.81 & 1.81 \\
\hline \multirow[t]{3}{*}{35.25} & Geraniol & 2.14 & 1.97 & 1.80 & 1.81 \\
\hline & Total & 100.00 & 100.00 & 100.00 & 100.00 \\
\hline & & \multicolumn{4}{|c|}{ 2018-2019 } \\
\hline 14.45 & dl-limonene & 1.31 & 1.44 & 1.09 & 0.51 \\
\hline 16.21 & Ç-terpinene & 5.91 & 7.23 & 7.28 & 7.33 \\
\hline 17.19 & Benzene, 1-methyl-2-(1-methylethyl) & 1.88 & 2.14 & 2.16 & 2.32 \\
\hline 25.13 & Decanal & 1.20 & 1.52 & 1.00 & 2.16 \\
\hline 25.99 & Camphor & 3.61 & 2.63 & 2.70 & 3.37 \\
\hline 26.53 & Linalool & 73.40 & 74.76 & 75.81 & 75.44 \\
\hline 26.78 & 1-octanol & 1.43 & 1.62 & 2.38 & \\
\hline 28.44 & 3-cyclohexen-1-ol, 4 methyl & 1.20 & 0.77 & 1.00 & 1.00 \\
\hline 32.86 & 1-Decanal & 6.44 & 5.63 & 4.96 & 5.28 \\
\hline 34.41 & Trans-2-dodecenil-ol & 0.83 & - & 0.53 & 0.86 \\
\hline \multirow[t]{2}{*}{35.25} & Geraniol & 2.30 & 0.97 & 1.09 & 0.92 \\
\hline & Total & 100.00 & 100.00 & 100.00 & 100.00 \\
\hline
\end{tabular}


Table 12. Essential oil components of Erbaa coriander variety (\%).

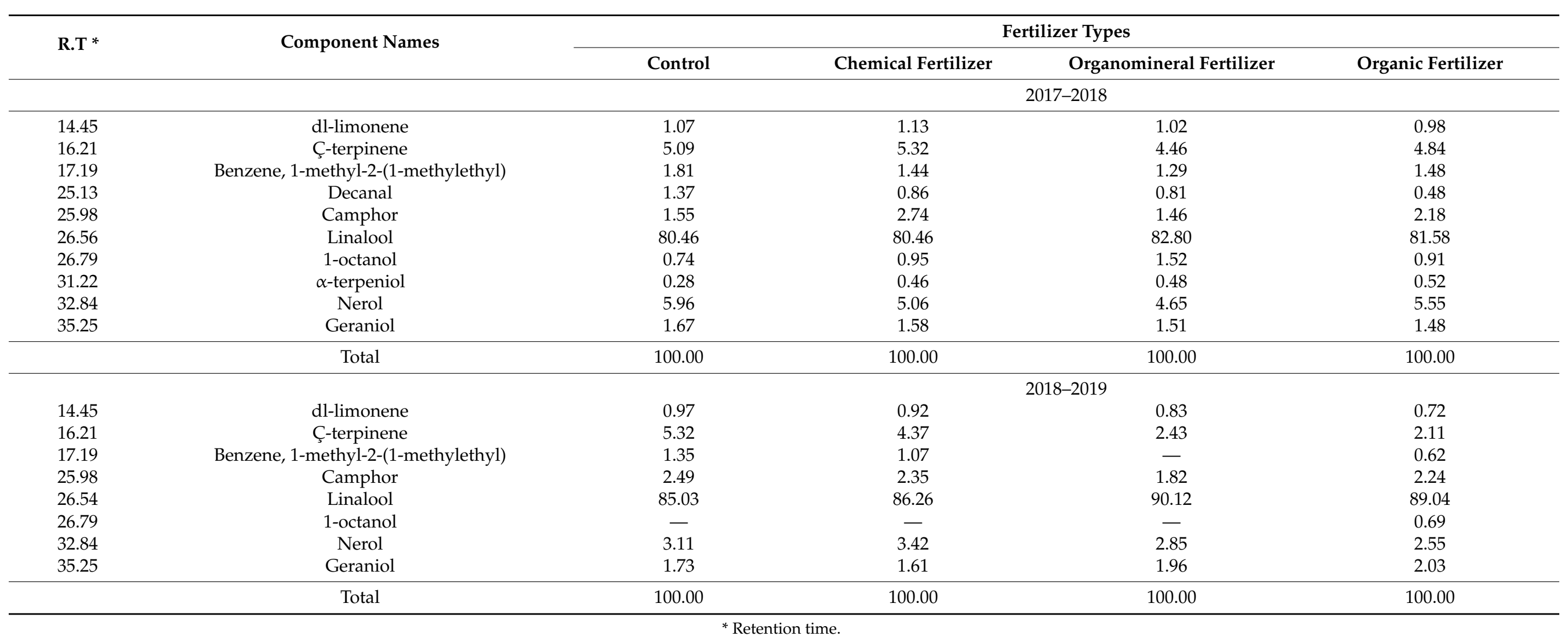




\section{Conclusions}

In current study, coriander genotypes were assessed under various fertilizer applications in semi-arid conditions. Results showed that the different fertilizers had significant influences in coriander genotypes for yield, yield components, and essential oil content. An increase in seed yield occurred with increasing rainfall. Results concluded that Erbaa cultivar in Siirt ecological conditions produced the maximum seed yield. Organic and organo-mineral fertilizers, which are very important for soil fertility, decompose slowly in the soil. For this reason, their influences on yield and yield components appear in the long term compared to chemical fertilizers. Although chemical fertilizers achieved the greatest results in term of the properties assessed in our study, when considering soil fertility and environment, organomineral fertilizers can be used partially or completely instead of chemical fertilizers.

Funding: This research was funded by Siirt University Scientific Research Project Coordinator with the project numbered SİÜ-ZİR-57.

Institutional Review Board Statement: Not applicable.

Informed Consent Statement: Not applicable.

Data Availability Statement: Not applicable.

Acknowledgments: The author thank Ayman ELSABAGH (Department of Field Crops, Faculty of Agriculture, Siirt University, Turkey) for his contributions to the editing and improvement of discussion for results to my paper.

Conflicts of Interest: The author declare no conflict of interest.

\section{References}

1. Chahal, K.K.; Singh, R.; Kumar, A.; Bhardwaj, U. Chemical composition and biological activity of Coriandrum sativum L.: A review. Indian J. Nat. Prod. Resour. 2018, 8, 193-203.

2. Mani, V.; Parle, M.; Ramasamy, K.; Abdul Majeed, A.B. Reversal of memory deficits by Coriandrum sativum leaves in mice. J. Sci. Food Agric. 2011, 91, 186-192. [CrossRef] [PubMed]

3. Inan, M.; Kirici, S.; Sultan Giray, E.; Murat, T.U.; Taghikhani, H. Determination of suitable coriander (Coriandrum sativum L.) cultivars for eastern mediterranean region. Turk. J. Field Crops 2014, 19, 1-6. [CrossRef]

4. Sourmaghi, M.H.S.; Kiaee, G.; Golfakhrabadi, F.; Jamalifar, H.; Khanavi, M. Comparison of essential oil composition and antimicrobial activity of Coriandrum sativum L. extracted by hydrodistillation and microwave-assisted hydrodistillation. J. Food Sci. Technol. 2015, 52, 2452-2457. [CrossRef] [PubMed]

5. Mahendra, P.; Bisht, S. Coriandrum sativum: A daily use spice with great medicinal effect. Pharmacogn. J. 2011, 3, 84-88. [CrossRef]

6. Nejad Ebrahimi, S.; Hadian, J.; Ranjbar, H. Essential oil compositions of different accessions of Coriandrum sativum L. from Iran. Nat. Prod. Res. 2010, 24, 1287-1294. [CrossRef]

7. İzg1, M.N.; Telci, İ.; Elmastaş, M. Variation in essential oil composition of coriander (Coriandrum sativum L.) varieties cultivated in two different ecologies. J. Essent. Oil Res. 2017, 29, 494-498. [CrossRef]

8. Satyal, P.; Setzer, W.N. Chemical compositions of commercial essential oils from Coriandrum sativum fruits and aerial parts. Nat. Prod. Commun. 2020, 15, 1934578X20933067. [CrossRef]

9. Ali, M.; Mujib, A.; Gulzar, B.; Zafar, N. Essential oil yield estimation by Gas chromatography-mass spectrometry (GC-MS) after Methyl jasmonate (MeJA) elicitation in in vitro cultivated tissues of Coriandrum sativum L. 3 Biotech. 2019, 9, 1-16. [CrossRef]

10. Diederichsen, A.; Banniza, S.; Armstrong-Cho, C.; Sander, T. Coriandrum sativum L.-Coriander. In Medicinal, Aromatic and Stimulant Plants; Springer: Cham, Switzerland, 2020; pp. 265-281.

11. Galata, M.; Sarker, L.S.; Mahmoud, S.S. Transcriptome profiling, and cloning and characterization of the main monoterpene synthases of Coriandrum sativum L. Phytochemistry 2014, 102, 64-73. [CrossRef]

12. Sharangi, A.B.; Guha, S.; Chakrabarty, I. Effect of different packaging materials on storage life of fresh coriander (Coriandrum sativum L.) leaves. Nat. Sci. 2015, 13, 100-108.

13. Priyadarshi, S.; Harohally, N.V.; Roopavathi, C.; Naidu, M.M. Isolation, identification, structural elucidation and bioactivity of Heneicos-1-ene from Coriandrum sativum L. foliage. Sci. Rep. 2018, 8, 1-6. [CrossRef]

14. Mandal, S.; Mandal, M. Coriander (Coriandrum sativum L.) essential oil: Chemistry and biological activity. Asian Pac. J. Trop. Biomed. 2015, 5, 421-428. [CrossRef]

15. Darughe, F.; Barzegar, M.; Sahari, M.A. Antioxidant and antifungal activity of Coriander (Coriandrum sativum L.) essential oil in cake. Int. Food Res. J. 2012, 19, 1253-1260. 
16. Puthusseri, B.; Divya, P.; Lokesh, V.; Neelwarne, B. Salicylic acid-induced elicitation of folates in coriander (Coriandrum sativum L.) improves bioaccessibility and reduces pro-oxidant status. Food Chem. 2013, 136, 569-575. [CrossRef]

17. Bhat, S.; Kaushal, P.; Kaur, M.; Sharma, H.K. Coriander (Coriandrum sativum L.): Processing, nutritional and functional aspects. Afr. J. Plant Sci. 2014, 8, 25-33.

18. Kajal, A.; Singh, R. An allied approach for in vitro modulation of aldose reductase, sorbitol accumulation and advanced glycation end products by flavonoid rich extract of Coriandrum sativum L. seeds. Toxicol. Rep. 2018, 5, 800-807. [CrossRef]

19. Prachayasittikul, V.; Prachayasittikul, S.; Ruchirawat, S.; Prachayasittikul, V. Coriander (Coriandrum sativum): A promising functional food toward the well-being. Food Res. Int. 2018, 105, 305-323. [CrossRef] [PubMed]

20. Kajal, A.; Singh, R. Coriandrum sativum improve neuronal function via inhibition of oxidative/nitrosative stress and TNF- $\alpha$ in diabetic neuropathic rats. J. Ethnopharmacol. 2020, 263, 112959. [CrossRef]

21. Ashraf, R.; Ghufran, S.; Akram, S.; Mushtaq, M.; Sultana, B. Cold pressed coriander (Coriandrum sativum L.) seed oil. In Cold Pressed Oils; Academic Press: Cambridge, MA, USA, 2020; pp. 345-356.

22. Singh, D.M.; Puri, D.; Sawhney, S.K.; Barman, M.; Bhardwaj, S.; Mishra, R.; Sharma, N.; Yasir, M. Nephroprotective Screening of Coriandrum sativum L. Leaves Against Gentamicin Induced Renaltoxicity in Wistar Albino Rats. J. Biol. Act. Prod. Nat. 2019, 9, 465-483. [CrossRef]

23. Sahoo, S.; Brijesh, S. Anxiolytic activity of Coriandrum sativum seeds aqueous extract on chronic restraint stressed mice and effect on brain neurotransmitters. J. Funct. Foods 2020, 68, 103884. [CrossRef]

24. Hojilla-Evangelista, M.P.; Evangelista, R.L. Effects of steam distillation and screw-pressing on extraction, composition and functional properties of protein in dehulled coriander (Coriandrum sativum L.). J. Am. Oil Chem. Soc. 2017, 94, 315-324. [CrossRef]

25. Silva, F.; Domeño, C.; Domingues, F.C. Coriandrum sativum L.: Characterization, Biological Activities, and Applications. In Nuts and Seeds in Health and Disease Prevention; Academic Press: Cambridge, MA, USA, 2020; pp. 497-519.

26. Wei, J.N.; Liu, Z.H.; Zhao, Y.P.; Zhao, L.L.; Xue, T.K.; Lan, Q.K. Phytochemical and bioactive profile of Coriandrum sativum L. Food Chem. 2019, 286, 260-267. [CrossRef]

27. Beyzi, E.; Karaman, K.; Gunes, A.; Beyzi, S.B. Change in some biochemical and bioactive properties and essential oil composition of coriander seed (Coriandrum sativum L.) varieties from Turkey. Ind. Crop. Prod. 2017, 109, 74-78. [CrossRef]

28. Carrubba, A. Organic and chemical N fertilization on coriander (Coriandrum sativum L.) in a Mediterranean environment. Ind. Crop. Prod. 2014, 57, 174-187. [CrossRef]

29. Singh, M. Effect of vermicompost and chemical fertilizers on growth, yield and quality of coriander (Coriandrum sativum L.) in a semi-arid tropical climate. J. Spices Aromat. Crop. 2012, 20, 30-33.

30. Darzi, M.T. Effects of organic manure and biofertilizer application on flowering and some yield traits of coriander (Coriandrum sativum). Int. J. Agric. Crop Sci. 2012, 4, 103-107.

31. Rajesh, K.; Singh, M.K.; Vijay, K.; Verma, R.K.; Kushwah, J.K.; Mahender, P. Effect of nutrient supplementation through organic sources on growth, yield and quality of coriander (Coriandrum sativum L.). Indian J. Agric. Res. 2015, 49, $278-281$.

32. Anonymous. Climate Data for Siirt Province. Records of the General Directorate of Meteorology, 2020.

33. Açıkgöz, N.; Açıkgöz, N. Some mistakes made in the statistical evaluation of agricultural research, 1. Single factor experiments. Anadolu J. AARI 2001, 11, 135-147.

34. Shahwar, M.K.; El-Ghorab, A.H.; Anjum, F.M.; Butt, M.S.; Hussain, S.; Nadeem, M. Characterization of coriander (Coriandrum sativum L.) seeds and leaves: Volatile and non volatile extracts. Int. J. Food Prop. 2012, 15, 736-747. [CrossRef]

35. Gil, A.; De La Fuente, E.B.; Lenard1s, A.E.; Pereira, M.L.; Suaärez, S.A.; Bandoni, A.; Van Baren, C.; Lira, P.D.L.; Ghersa, C.M. Coriander essential oil composition from two genotypes grown in different environmental conditions. J. Agric. Food Chem. 2002, 50, 2870-2877. [CrossRef] [PubMed]

36. Javed, T.; Shabbir, R.; Ali, A.; Afzal, I.; Zaheer, U.; Gao, S.J. Transcription factors in plant stress responses: Challenges and potential for sugarcane improvement. Plants 2020, 9, 491. [CrossRef] [PubMed] 